\title{
Study Habit in Remote Learning Education: A Basis for Teachers Modern Pedagogical Strategies in Tertiary Level
}

\author{
Romel C. Tuliao, LPT, MAED, Dave M. Pastorfide, MBA, LPT
}

Faculty Members, College of Management and Business Technology-Nueva Ecija University of Science and Technology San Isidro Campus, Tabon Annex, San Isidro, Nueva Ecija Philippines

Received: 03 Mar 2021; Received in revised form: 21 Apr 2021; Accepted: 14 May 2021; Available online: 29 May 2021

\begin{abstract}
According to the study of Korir, D. and Kipkemboi F. (2014), School as a second home has a solid relationship to the academic performance of the students. However, because of the pandemic, home seems to become the second School of the students, affecting their study habits. Thus, this study was conducted to determine the factors that affect the students' study habits at the tertiary level using remote learning mode of education. The study used a descriptive-quantitative research design, and a self-made questionnaire is a primary tool in gathering data. Simple statistical tools were used to interpret the data. A total of 375 students from Nueva Ecija University of Science and Technology - San Isidro Campus, San Isidro Nueva Ecija, Philippines 3106 are the study respondents. The results show that students used their free time to study, and most of them use 2 hours and above to study, which shows why most students are able to cope with the current education model. It also shows that the students' environment dramatically affects the study habits of the students, thus, another reason why most students are struggling to survive in their online/remote learning mode of education.
\end{abstract}

Keywords - Study Habit, Remote Learning, Education, Tertiary Level, Pedagogical Strategy.

\section{INTRODUCTION}

Education in the present time has changed a lot since Covi19 Pandemic hits the country. As mandated by the government, all schools are forced to stop face-to-face class in response to the slowdown, if not eliminate the virus's spread. Children in the Philippines are not going to go to school until a Covid-19 vaccine is available, officials said, causing fears that millions of students might be left without access to education(Theguardian.com). True to its mission to keep the learning going, Secretary Leonor Magtolis Briones and other Southeast Asian ministers of education, in response to the COVID-19 global crisis, presented their different educational strategies during the first ministerial e-forum on Southeast Asian Ministers (SEAMEO) held last Thursday, June 18 (DepEd, 2020). The department of education, which is committed to providing quality education for Filipino people, looks for a different opening class strategy, and one of these and is being implemented now is Remote Learning education. In the Philippines and the USA, schools have implemented remote learning in response to the spread of COVID-19, a new Coronavirus(Morgan, 2020).

Remote Learning education is the non-face-toface mode of learning. Remote learning aims to re-create the environment in the classroom as students learn on the computer. It means that the student logs into the virtual classroom at scheduled times to see lectures or participate(Geneva.edu, 2020). It also means to deliver education to the students, such as the use of the internet, printed materials, and computer. In remote learning, students can learn and do their school activities even when they are at home.

Using this model of education, also change the strategies of teachers in delivering lessons and conducting their class to their students. Teaching pedagogy continuously evolves as the education system evolves. According to Harper et al. (2004), pedagogy must be kept changing and growing as technology changes.

This article can be downloaded from here: www.ijaems.com 
These profound changes in the students' learning modality affect not only the teaching pedagogy but also the student's study habit of learning in their time. That's the habits that students form in their years of education. A student cannot succeed without good study habits(Ebele and Olofu, 2017). Habit is a practise of a routine that practice does consistently. Different study habits are developed for students where education is implemented. Learners' needs include different learning styles, which can influence learning performance(Çakıroğlu). Study habits act as another variable connected with distance learners' performances. Study habits reflect students' usual act of studying and call forth and direct the learner's cognitive processes during learning(Proctor et al., 2006). Thus, this study was conducted to identify the factors that affect students' study habits during this mode of education.

This study would help the teachers to chose and develop the appropriate strategy in teaching. It will also help the administrators of the school in their plans in implementing the mode of learning. Lastly, the student will be aware of the different habits that others are doing to have effective learning.

\section{OBJECTIVE OF THE STUDY}

This study aims to determine the different study habits among learner during the implementation of Remote Learning (RL) in Higher Education Institutions (HEI). Specifically, it attempts to:

1. Demographic profile of the respondents

2. Length and schedule of Study Habit of the Respondents

3. The effects of the following factors to the student habits of respondents

4. Challenges encountered by the respondents in their study habit.

\section{METHODOLOGY}

This study used a descriptive-quantitative research design. Descriptive research is usually defined as a type of quantitative research, though qualitative research can also be used for descriptive purposes(McCombes, 2020). This study was conducted to determine the effects of different factors in students' study habits.

This study's respondents were the 375 students in different courses of Nueva Ecija University of Science and Technology - San Isidro Campus, San Isidro, Nueva Ecija Philippines 3106 . ). The primary tool used to gather data is a self-made questionnaire. It is collecting data through an instrument consisting of a series of questions and prompts to receive a response from individuals it is administered.
Questionnaires are designed to collect data from a group(Formplus.com).

The respondents' responses were organized, classified, tabulated, analyzed, and interpreted using frequency distribution, percentage, and ranking. All Computations were done using Microsoft Excel.

\section{RESULTS AND DISCUSSION}

This section presents the survey results concerning the study habits of the students of Nueva Ecija University of Science and Technology - San Isidro Campus, San Isidro Nueva Ecija University of Science and Technology.

\section{Demographic Profile of the Respondents} 1.1. Age of the Respondents

\section{Figure 01: Age of the Respondents} Figure 01

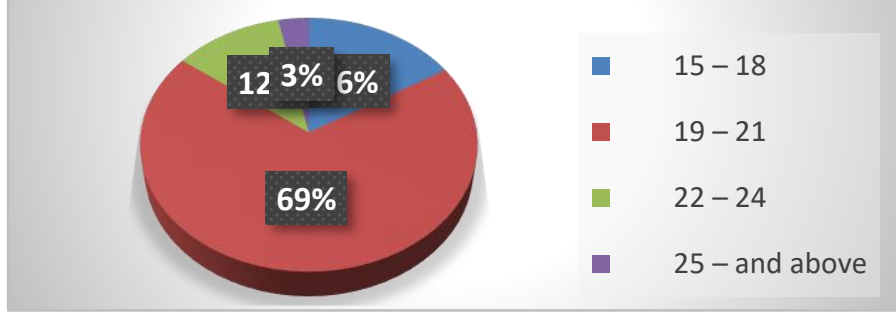

The data shows in figure 01 that most or $69 \%$ of the respondents are between the ages of 19-21 which is appropriate to be a college student. Data is supported by the Philippine Education System (2021) states that most Bachelor Degree for four years is usually 17-20 years old.

\section{Figure 02: Gender of the Respondents}

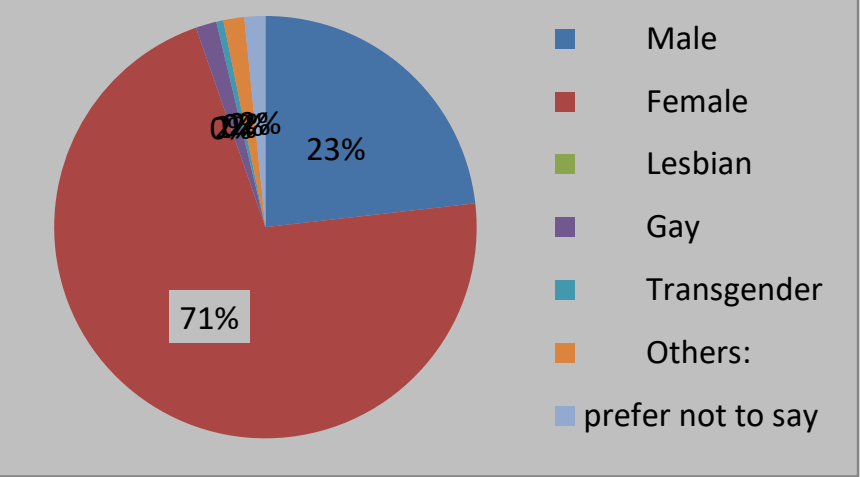

\subsection{Gender of the Respondents}

Figure 02 states that $71 \%$ of the respondents are female far from the number of males that is only $24 \%$ of 
the total respondents. The data proves that the majority of the college students are women that emphasize from the 1990s onwards, men have begun to perform less well in higher education compared to women (Evers and Mancuso 2006; Jorgensen et al. 2009; OECD 2008).

\subsection{Year Level of the Respondents}

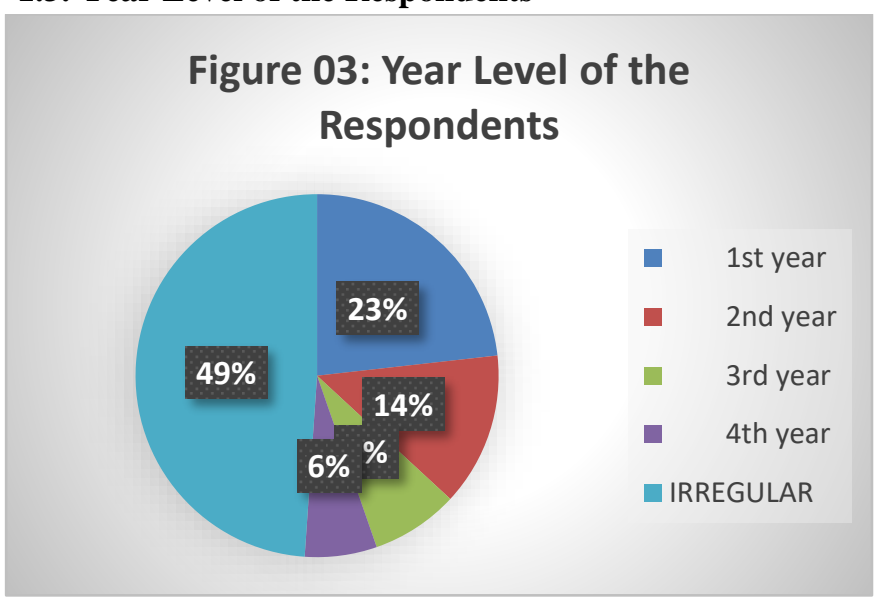

The figure 03 shows that $49 \%$ or majority of the respondents are $1^{\text {st }}$ Year students. Thus, this figure emphasizes that $1^{\text {st }}$ year students are more active than in any other year level because this is their discovery stage in their college's life as agreed by Habibah et.al (2011) in their findings that the first-year students had low stress level.This only proves that since they are freshmen their eagerness and willingness to learn as college students are still there.

\subsection{Course of the Respondents}

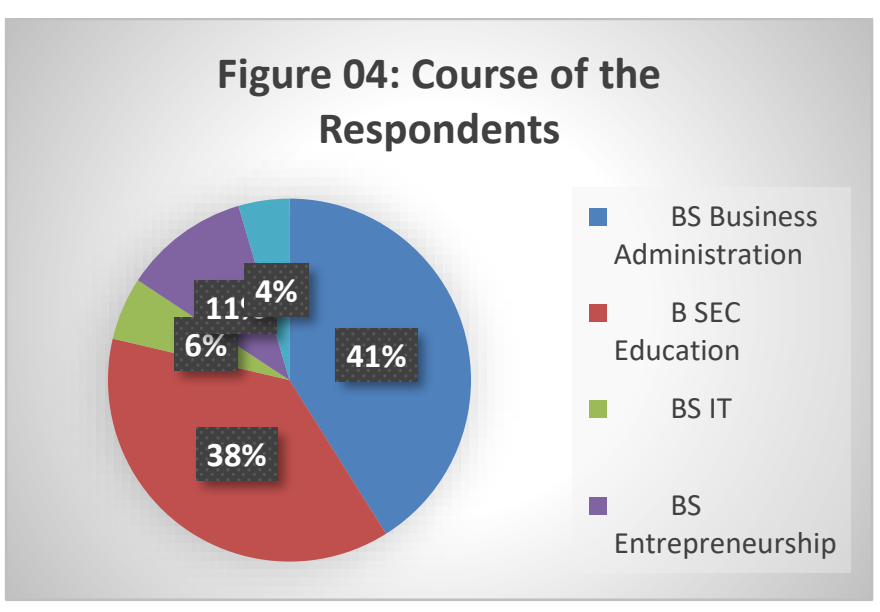

In figure 04, indicates that $41 \%$ of the respondents are from BSBA (Bachelor of Science in Business Administration). Seconded by the respondents from B SEC Education with $38 \%$. The reason of this is 60 $\%$ of the total population of the whole campus (NEUSTSIC) is coming from the BSBA (Bachelor of Science in Business Administration)

\subsection{Units Enrolled by the Respondents}

\section{Figure 05: Units Enrolled by the} Respondents

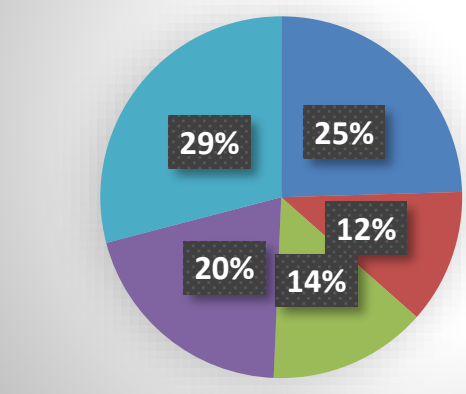

15units and below

-16-18units

19-21units

- 22-24units

25units and above

Figure 05 shows that $29 \%$ of the respondents are enrolled with 25 units and above, this data is parallel in the Revised-UP Code: Art. 338 p. 85, states that "a regular freshman is a student who has not finished the prescribed subjects of the first year of his/her curriculum or has finished only or less than 25 percent $(25 \%)$ of the total number of units required in the entire course"In short, the subjects of the respondents are ranging from 8-10 subjects a week times 3 hours per subject, with a total of 30 hours a week. The average subject per day is $3-5$, which shows that the respondents have enough time or have time for them to study their lessons every day.

\subsection{Mode of Learning Used by the Respondents}

\section{Figure 06: Mode of Learning Used by the Respondents}

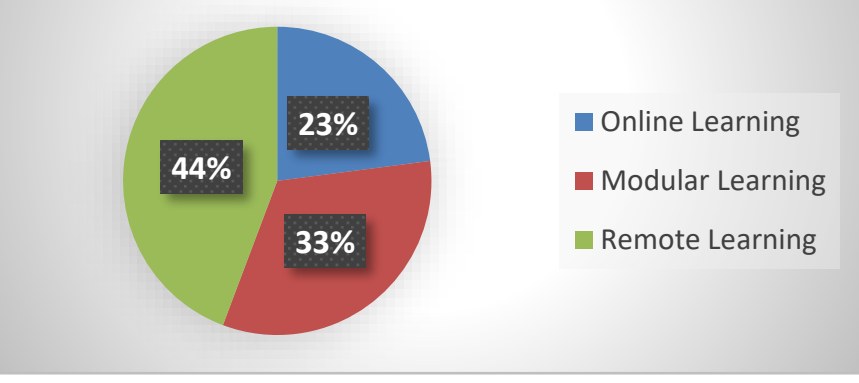

It is clearly shown in the Figure 06 that majority of the respondents (44\%) are on the Modular Learning. The figure only certifies the study of Mina et.al. (2020) that that majority of the learners in the same institution do not have an internet provider at home. Since, modular learning does not need so much internet connection because the activities and lectures are already in the module. That provides the respondents more time to study and understand the lessons in the modules. 


\subsection{School Graduated in Senior High School by the Respondents}

\section{Figure 07: School Graduated in Senior High School by the Respondents}

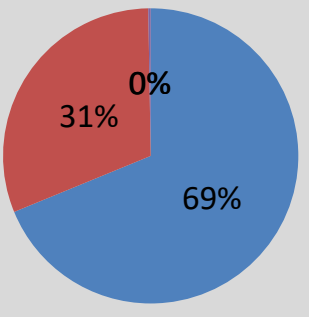

Public

Private

Special School

Figure 07 shows that $69 \%$ of the respondents graduated from public schools while only $31 \%$ of them come from the private school nearby the University understudy, thus the result of these figures shows that the majority of the students of this university preferred to study in a government school as what they were graduated in their Senior High School. This only means that parents of the respondents decided to enroll them in public school for an economic reason but still, they can learn the expected knowledge that they must learn on the course that they choose as what private students are expected to learn in the same course.

In this regards, Ali (2012) proves that "it may be predicted that private school students had stronger study habits than those attending public schools. Private school students study regularly. Public students are likely to study last minute. Private schools have a greater amount of total study hours. However, public school students tend to study in complete silence, while private school students' study while watchingTv or listening to music, lacking focus".

\subsection{Family Annual Income (Approximately) of the Respondents}

Figure 08: Family Monthly Income (Approximately) of the Respondents

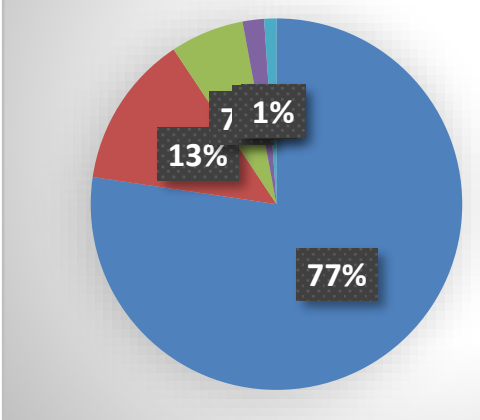

P10,000 and below

- $P 10,0001-15,000$

P15,001 - 20,000

口 $\mathrm{P} 20,001-25,000$

- P25,001 and above
The data in figure 08 shows that the majority of the respondents or $71 \%$ of them stated that the approximately monthly income of their family is P10,000 and below. Base on the "Income Groups in the Income Distribution, Income Thresholds and Sizes of Income Groups in 2018" states that a family with a monthly income of less than P 11,000 is classified as "Poor". This only shows that the majority of the respondents are classified their family as "poor" when they choose the monthly income of P10,000 and below.

Figure 08 support the data in figure 06 that $69 \%$ are graduated in public schools in their SHS and also decided to enrolled in SUC for them to have a free education to porsue their closen carrer or profession.

\section{LENGTH and SCHEDULE of Study Habit of the Respondents}

2.1. Average time per day spent for personal study

Figure 09, Average Time per Day Spent for Personal Study of the Respondents

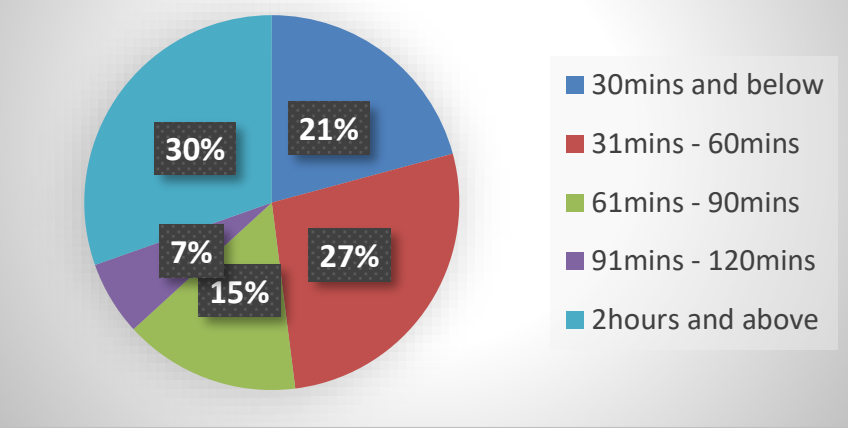

The result of figure 09 are very close to each other, $30 \%$ of the respondents used 2 hours and above as their average time per day spent for personal study, followed by $27 \%$ used 31 minutes to 1 hour, and the third is 30 minutes and below consumes their time in their personal study.

Supporting this finding, Awolabi (1996) explains that there is a significant difference between thirty (30) minutes study time and one-hour academic performance ratings of students. According to him, thirty minutes study time is not academic performance oriented, as it often leads to poor examination grade. Awolabi maintains that a combination of the study time and other factors explain students' academic performance in any course of study. In the same way, Adeyemo (2005), opined that study time is a pattern of activity that goes beyond merely reading for pleasure.

A student who wants to graduate with good grade has to read his/her books with understanding, and that will 
take more time to accomplish. In the same vein Kunal (2008), observes that students who are very successful in their desired career have longer study time. It is stated in the website that students who apply these attitudes in all of their courses, always come out successful. It is necessary for students to develop good study habits in order to know how long it will take them to study and understand their course of study. Supporting this finding, Dika (2002) agreed that a grade is a primary parameter showing such learning (Uklong and George, 2013)

\subsection{Time used for personal study of the respondents}

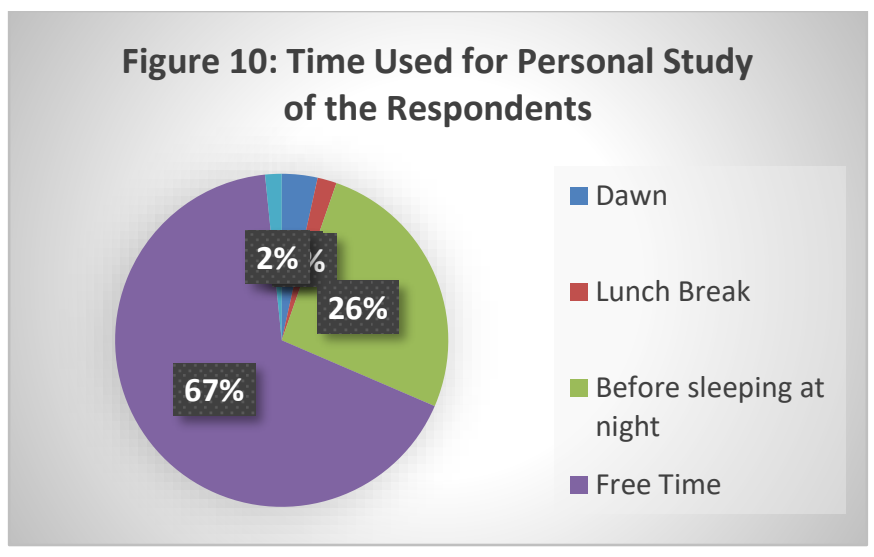

Figure 10 shows that $67 \%$ of the respondents used their free time in school as their study time in reviewing their lessons, reports, and other related activities. This data proves that no particular time in a day may consider as the best time for studying as supported by

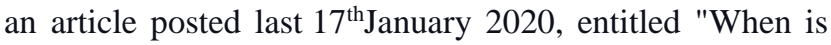
the Best Time to Study: Morning, Noon or Night?" in PSB Academy, emphasizes that different timings work for different students and you can find your best time of the day to study if you consider the following factors. Firstly, when are you most alert? Think about that, but different qualities of memories and alertness seem to be better at different times of the day for different people. For example, you can have a better visual memory in the morning, but your critical thinking ability peaks in the afternoon. Secondly, if your optimal time is prone to distractions, such as dinner time, which might disrupt your routine, It is best to find another timing. Lastly, make sure you select a time that you can stick to consistently, at least for a few days every week because consistency helps ensure you study daily and improves the quality of your study time.

Just like each student has a unique learning style, different students may learn better at different times of the day. But if you study at the same time every day, you will condition your mind and body gradually, and soon, you will be in your best frame of mind for study. Once you know what works best for you, you can start your studying routine more effectively and efficiently.

To further elucidate that findings here are the two habits from the "10 Habits of Highly Effective Students" by Loveless (2021)

1. Plan when you're going to study.

Successful students schedule specific times throughout the week when they are going to study -and then they stick with their schedule. Students who study sporadically and whimsically typically do not perform as well as students who have a set study schedule. Even if you're all caught up with your studies, creating a weekly routine, where you set aside a period a few days a week, to review your courses will ensure you develop habits that will enable you to succeed in your education long term.

2. Study at the same time.

Not only is it important that you plan when you're going to study, it's important you create a consistent, daily study routine. When you study at the same time each day and each week, you're studying will become a regular part of your life. You'll be mentally and emotionally more prepared for each study session and each study session will become more productive. If you have to change your schedule from time to time due to unexpected events, that's okay, but get back on your routine as soon as the event has passed. (Loveless, 2021).

\section{The EFFECTS of the Following FACTORS to the Study Habits of Respondents}

Table 01: Specific factors affecting the Study Habits of Respondents

\begin{tabular}{|l|l|l|l|}
\hline $\mathbf{N o}$ & Indicator & $\begin{array}{l}\text { Weighte } \\
\text { d Mean }\end{array}$ & $\begin{array}{l}\text { (Verbal } \\
\text { Interpretatio } \\
\text { n) }\end{array}$ \\
\hline $\mathbf{1}$ & $\begin{array}{l}\text { Environment/Commun } \\
\text { ity of the } \\
\text { learner/respondent }\end{array}$ & 3.12 & $\begin{array}{l}\text { A } \\
\text { (Affected) }\end{array}$ \\
\hline $\mathbf{2}$ & $\begin{array}{l}\text { Interest related to the } \\
\text { Course Enrolled of the } \\
\text { learner/respondent }\end{array}$ & 3.05 & $\begin{array}{l}\text { A } \\
\text { (Affected) }\end{array}$ \\
\hline $\mathbf{3}$ & $\begin{array}{l}\text { Work/Duty related } \\
\text { Issues of the } \\
\text { learner/respondent }\end{array}$ & $\begin{array}{l}\text { A } \\
\text { (Affected) }\end{array}$ \\
\hline $\mathbf{4}$ & $\begin{array}{l}\text { Family/Relatives } \\
\text { Related Problems of } \\
\text { the learner/respondent }\end{array}$ & 2.89 & $\begin{array}{l}\text { NA } \\
\text { (Not Affected) }\end{array}$ \\
\hline
\end{tabular}

The data in table 01 signifies that the number 1 specific factors affecting the study habits of respondents are their 
"Environment or Community' which $3.12 \%$, these findings agreed to Ozmert (2015) emphasized the importance of environmental influence as a major factor in the development of students studying habits. Although it is good to study in a peaceful environment sometimes students cannot get that environment. In this manner, students should have to adjust themselves in that environment like, in noisy classrooms or hostels some students study in silence but some do not. If they have good study habits, they can adjust easily. Some students cannot cope up with the non-suitable environment. Due to this reason, some students lose their positions. Effective study habits help students to achieve good results (Sadia, 2005).

Followed by "Interest related to the Course Enrolled of the respondents" which is $3.05 \%$, Most of the respondents are taking their course it is not because they want it or it is their line of interest, they took the course because it is free. And another reason is a general notion or a fact that only education can free us from poverty. This statement certifies the data gathered in figure 6 that most of the respondents are graduates of public schools and further certifies in figure 07 that most of the respondents signify that their monthly family income is below P10,000.

The third factor is "Work or Duty related Issues of the respondents which are $2.89 \%$, thus also correlated to the data in figure 06 (monthly family income) for them to survive while studying is to earn an extra income for their financial support.

\subsection{Other factor given by the respondents}

Table 2: Other factors given by the respondents

\begin{tabular}{|c|c|c|c|}
\hline $\begin{array}{l}\text { Ran } \\
\mathbf{k}\end{array}$ & Factors & $\begin{array}{l}\text { Frequen } \\
\text { cy }\end{array}$ & $\begin{array}{l}\text { Percenta } \\
\text { ge }\end{array}$ \\
\hline 1 & Time Management & 71 & $19 \%$ \\
\hline 2 & $\begin{array}{l}\text { Resources,gadget,equipm } \\
\text { ents for study }\end{array}$ & 50 & $13 \%$ \\
\hline 3 & Personal Problems & 41 & $11 \%$ \\
\hline 4 & Internet Connections & 31 & $8 \%$ \\
\hline 5 & Social Media & 25 & $7 \%$ \\
\hline \multirow{2}{*}{6.5} & $\begin{array}{l}\text { Distraction } \quad \text { from } \\
\text { surounding/neigborhood }\end{array}$ & 14 & $4 \%$ \\
\hline & $\begin{array}{l}\text { What others says/ } \\
\text { comment/ critism }\end{array}$ & 14 & $4 \%$ \\
\hline \multirow[t]{3}{*}{8} & House responsibility & 5 & $1 \%$ \\
\hline & No answer & 120 & $33 \%$ \\
\hline & TOTAL & 375 & $100 \%$ \\
\hline
\end{tabular}

This article can be downloaded from here: www.ijaems.com
As shown in Table 2, are the lists of specific factors affecting the study habits of respondents that they have given are interrelated like; rank 3 is "Personal problem" (41 frequency or $11 \%$ of the respondents), rank 6.5 with 14 frequency or $4 \%$ of the respondents are "Distraction from surrounding or neighborhood" and "What others say or comment/criticism", and "House responsibility" with 5 frequency or only $1 \%$ of the respondent. Those factors mentioned have a big impact on rank number 1 which is "Time management" with 71 frequency or $19 \%$ of the total respondents mentioned. The above given specific factors that respondents gave are the manifestations of the result in Table 1 which is the main factor identified by the respondents as rank one is "Environment/Community of the learner/respondent".

While rank 2 which is "Resources, gadgets, study equipment",rank 4 "Internet Connections", and rank 5 "Social Media" are also connected which further proves the result in figure 6 regarding the respondents "family monthly income".

But as notice on the same table, $33 \%$ or 120 respondents do not give anymore specific examples because almost all the possible factors affecting the study habit of the respondents are given already in table 1 .
4. Challenges
Encountered
by
the
Learners/Respondents in their Study Habit

Table 3. Challenges encountered by Learners/Respondents in their study

\begin{tabular}{|c|c|c|c|}
\hline No. & Indicator & $\begin{array}{l}\text { Weighted } \\
\text { Mean }\end{array}$ & $\begin{array}{l}\text { Verbal } \\
\text { Interpretation }\end{array}$ \\
\hline 1 & $\begin{array}{l}\text { a. Time Pressure in } \\
\text { their studies }\end{array}$ & 3.47 & $\begin{array}{l}\text { Strongly } \\
\text { Agree (SA) }\end{array}$ \\
\hline 2 & b. Mode of Learning & 3.30 & $\begin{array}{l}\text { Strongly } \\
\text { Agree (SA) }\end{array}$ \\
\hline 3 & $\begin{array}{l}\text { c. Resources (e.g. } \\
\text { cellphone, modules, } \\
\text { etc.) }\end{array}$ & 3.44 & $\begin{array}{l}\text { Strongly } \\
\text { Agree (SA) }\end{array}$ \\
\hline 4 & $\begin{array}{l}\text { d. Study Habit } \\
\text { Behavior }\end{array}$ & 3.20 & Agree (A) \\
\hline 5 & e. Family Issues & 2.76 & Agree (A) \\
\hline 6 & $\begin{array}{l}\text { f. Financial } \\
\text { Issues/Problems }\end{array}$ & 3.12 & Agree (A) \\
\hline 7 & $\begin{array}{l}\text { g. Work Related } \\
\text { Issues }\end{array}$ & 2.17 & Disagree (D) \\
\hline & $\begin{array}{l}\text { Average Weighted } \\
\text { Mean }\end{array}$ & 3.07 & Agree (A) \\
\hline
\end{tabular}

Table 3, shows the "Challenges Encountered by the Respondents in their Study Habit", the respondents 
"strongly agreed" the following challenges "Time Pressure in their studies", "Mode of Learning", and "Resources (e.g. cellphone, modules, etc.)". The mentioned challenges point out the most common factors that are given by the respondents in table 3 and emphasizes its relationship in table 1 .

\section{CONCLUSION AND RECOMMENDATION}

From the data presented above, a conclusion was made. The result shows that majority of the respondents have an approximately P10,000 income monthly. This can be related why most of the students are using their free time to study and most of them are spending 2hours of their time to study as part of their study habit. This shows the reason why students can cope up in their study. In the factors that affects the study habits of the students, it shows that environment has the highest mean that affects students, since they are studying at their house, most of the students based on their approximate income monthly does not have a good environment which really affects their study habit. This is also shown on the challenges of students in their study habit are the Mode of learning that is the Remote learning. The environment of the students are different from one another that why one teaching strategy of teachers for all students might not be effective to some of them if not majority.

The researchers strongly suggests that school administrators conduct further studies of the different environment of the students and how they will be able to help the students based on the kind of environment they have. It will greatly help them in their study habit if their environment will be suitable for learning. To the teachers, it is suggest that they observed the pattern or routines of the students in complying to their requirements.

\section{REFERENCES}

[1] Theguardian.com. Global report: Philippines says schools won't open until there is a Covid19 vaccine. Retrieved on March 16, 2021 from: https://www.theguardian.com/world/2020/jun/09/globalreport-philippines-says-schools-wont-reopen-until-there-isa-covid-19-vaccine

[2] DepEd, 2020. Briones, education ministers unite to ensure learning continuity amid COVID-19. Retrieved on March 16, 2021, from: https://www.deped.gov.ph/2020/06/24/briones-educationministers-unite-to-ensure-learning-continuity-amid-covid$\underline{19 /}$

[3] Morgan H. 2020. Best Practices for Implementing Remote Learning during a Pandemic. Retrieved on March 16, 2021 from: https://doi.org/10.1080/00098655.2020.1751480
[4] Geneva College, 2020. Online Education vs Remote Learning Education. Retrieved on March 16, 2021, from: https://www.geneva.edu/blog/higher-education/onlineeducation-vs-remotelearning\#: :text=Remote $\% 20$ learning $\% 20$ strives $\% 20$ to $\% 2$ Ore,participate\%20in\%20group\%20learning\%20activities.

[5] Harper, K. C., Chen, K., \& Yen, D. C. (2004). Distance learning, virtual classrooms, and teaching pedagogy in the Internet environment. Technology in Society, 26(4), 585598.

[6] Ebele U. and Olofu P. 2017. Study habit and its impact on secondary school students' academic performance in biology in the Federal Capital Territory, Abuja. Retrieved on March 16, 2021, from: https://files.eric.ed.gov/fulltext/EJ1143649.pdf

[7] Ünal Çakıroğlu. Analyzing the Effect of Learning Styles and Study Habits of Distance Learners on Learning Performances: A Case of an Introductory Programming Course. Retrieved on March 16, 2021, from: https://files.eric.ed.gov/fulltext/EJ1039811.pdf

[8] Ünal Çakıroğlu. Analyzing the Effect of Learning Styles and Study Habits of Distance Learners on Learning Performances: A Case of an Introductory Programming Course. Retrieved on March 16, 2021, from: https://files.eric.ed.gov/fulltext/EJ1039811.pdf

[9] McCombes, S. 2020. Descriptive Research. Retrieved on March 17, 2021, from: https://www.scribbr.com/methodology/descriptiveresearch/

[10] Formplus.com 2020. 7 Data Collection Methods \& Tools For Research. Retrieved on March 17, 2021, from: https://www.formpl.us/blog/data-collectionmethod\#: :text=What\%20is\%20a\%20Data\%20Collection,t ools $\% 20$ used $\% 20$ to $\% 20$ collect $\% 20$ data.

[11] 2021 Web Solutions LLC. and Its Licensors ps://education.stateuniversity.com/pages/1199/PhilippinesEDUCATIONAL-SYSTEM-AN-OVERVIEW.html Published: 24 August 2011

[12] Leaving College: A Gender Comparison in Male and Female-Dominated Program $\underline{\text { Sabine Severiens } \& \text { Geert ten }}$ $\underline{\text { Dam }}$

[13] Front. Comput. Sci., 12 November 2019 | https://doi.org/10.3389/fcomp.2019.00007

[14] A Comparative Analysis of Student Performance in an Online vs. Face-to-Face Environmental Science Course From 2009 to 2016 Jasmine Paul $^{*}$ and Felicia Jefferson

[15] International Conference on Education and Educational Psychology (ICEEPSY) Stress and Academic Achievement among Undergraduate Students in Universiti Putra Malaysia Habibah Elias*, Wong Siew Ping, Maria Chong Abdullah Faculty of Educational Studies, Universiti Putra Malaysia, 43400 UPM Serdang, Selangor Darul Ehsan, Malaysia. Revised UP Code: Art. 338 p. 85)

[16] Academic Achievements and Study Habits of College Students of District Pulwama Bhat Younes Illahil Dr.Hemant Khandai2 Vol.6, No.31, 2015

[17] Relationship between Home Environment and Study Habit of Senior Secondary School Students DR. REENA RANI 
Assistant Professor, Institute of Teacher Training and Research, BPSMV, Khanpur Kalan, Sonipat (Vol. 2, Issue:7, July 2013)

[18] "Study Habits and Education Planning: A Case Study of Comparison or Private and Public sector schools" by Arshad Ali, Zulfiquar Ali and Ramin Naz 2012

[19] Income Groups in the Income Distribution, Income Thresholds and Sizes of Income Groups in 2018

[20] Length of Study-Time Behaviour and Academic Achievement of Social Studies Education Students in the University of Uyo D. E. Ukpong1 \& I. N. George1 (Vol. 6, No. 3 ;

2013) https://files.eric.ed.gov/fulltext/EJ1067747.pdf

[21] PSB ACADEMY Whenisthe Best Timeto Study: Morng, Noonor Night? Posted on: 17th January, 2020

[22] 10 Habits of Highly Effective Students by Becton Loveless Copyright 2021 Educationcorner.com. All rights reserved https://www.educationcorner.com/habits-of-successfulstudents.html

[23] FACTORS AFFECTING STUDY HABIT AND ACADEMIC PERFORMANCE: A CASE STUDY OF NATIONAL OPEN UNIVERSITY STUDY CENTER. NATIONAL OPEN UNIVERSITY STUDY CENTER.FEBRUARY 12, 2019 PROJECTEASY LEAVE A COMMENT

[24] Korir, D. K., \& Kipkemboi, F. (2014). The impact of school environment and peer influences on students' academic performance in Vihiga County, Kenya. 